\title{
Chapter 16 \\ Margaret Ann Harvey Neve - 110 Years Old in 1903. The First Documented Female Supercentenarian
}

\author{
Michel Poulain, Dany Chambre, and Bernard Jeune
}

Margaret Ann Harvey was born on 18 May 1792 on Pollet Street in the centre of St Peter Port in Guernsey, and was baptised 10 days later in the nearby Town Church, according to a record in French in the parish register, which is conserved in the Priaulx Library (Fig. 16.1): Marguerite Anne, daughter of Sire Jean Harvey and Elizabeth Guille, his wife, born on 18 May 1792 and baptised on the 28th of the same month; her 'Parrain' was Sire Nicolas Le Patourel and her 'Marraine' were Elizabeth Guilmotte and Marie Elizabeth Guille.

The island of Guernsey is the second-largest of the Channel Islands after Jersey, and is situated about $50 \mathrm{~km}$ from Normandy in France. Today, Guernsey is a dependency of the British Crown without being strictly part of the United Kingdom or a member of the European Union.

The parents of Margaret Ann were John Harvey and Elizabeth Guille. Her father was born on 3 July 1771 and died on 4 December 1820 at the age of 49, whereas her mother was born on 10 November 1771 and died on 1 May 1870 at the exceptional age of 98 . Both of her parents spent their whole lives in Guernsey, and were married in the Town Church of St Peter Port on 21 December 1790 (Fig. 16.2).

Margaret Ann was the first of eight children born between 1792 and 1806 (Table 16.1). We found the dates of birth and death of all of her siblings, and the contents of all of their baptism and death records have been carefully checked. All

\author{
M. Poulain $(\bowtie)$ \\ Université catholique de Louvain, Ottignies-Louvain-la-Neuve, Belgium \\ Tallinn University, Tallinn, Estonia \\ e-mail: michel.poulain@uclouvain.be \\ D. Chambre \\ Gerontologist, Estaimpuis, Belgium \\ e-mail: dchambre@skynet.be \\ B. Jeune \\ University of Southern Denmark, Odense, Denmark \\ e-mail: BJeune@health.sdu.dk




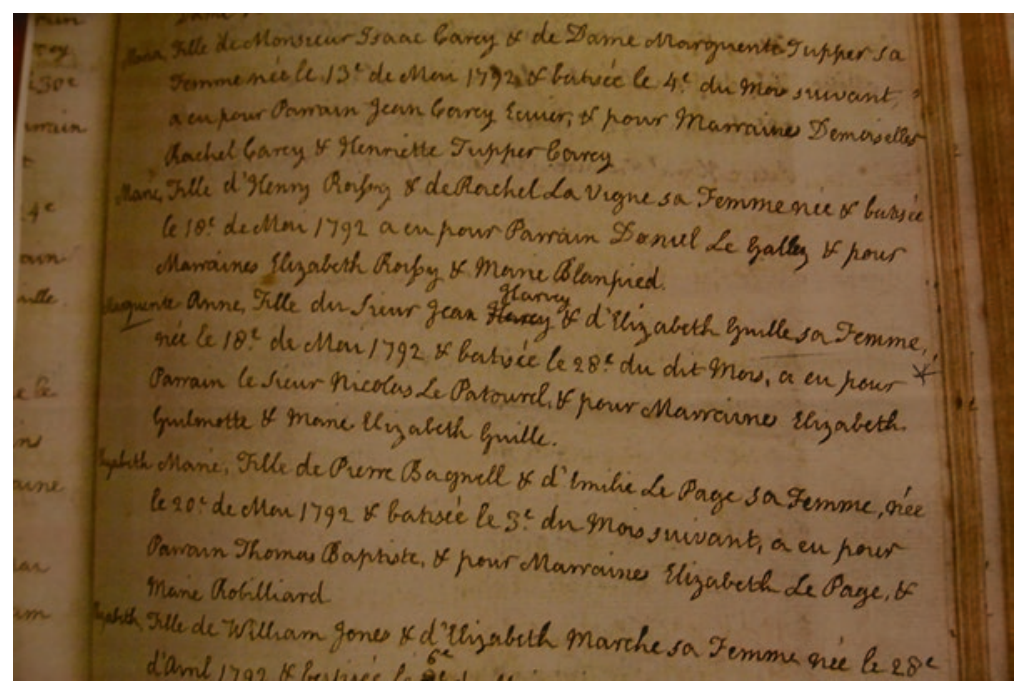

Fig. 16.1 The baptism record of Marguerite Anne HARVEY born on18 May 1792 in St Peter Port (Priaulx Library)

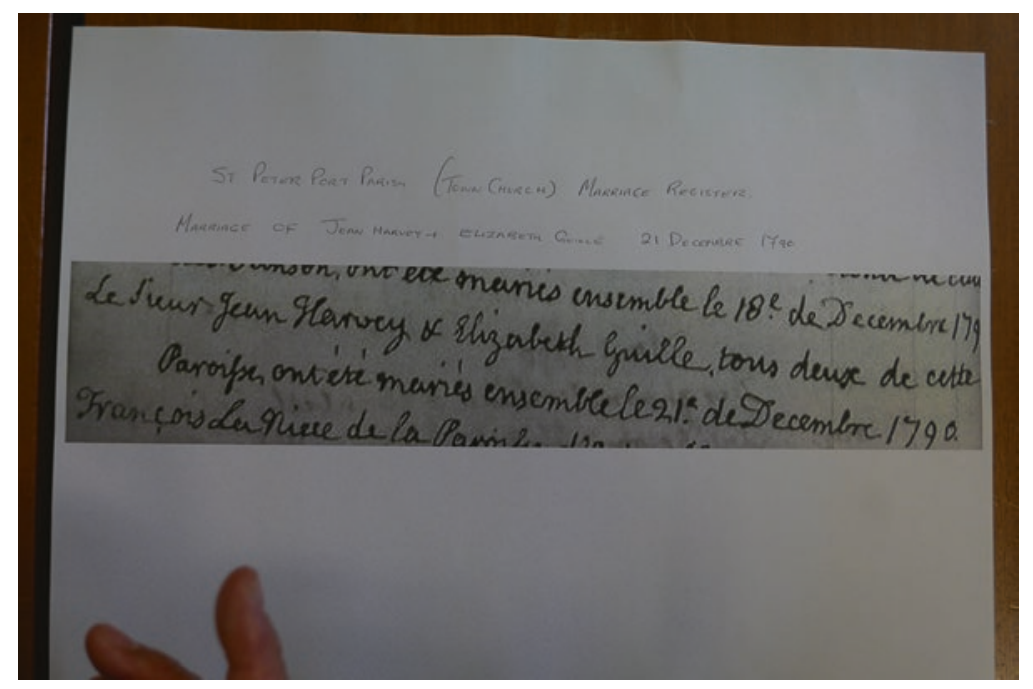

Fig. 16.2 The marriage record of John HARVEY and Elizabeth GUILLE in St Peter Port on 21 December 1790 (Priaulx Library)

of her siblings were born and died in St Peter Port, except Thomas, who emigrated first to Jersey and thereafter to Oregon in the US, where he died in Portland. Only two of Margaret Ann's sisters died before 5 years of age: Augusta, who was born on 6 November 1797 and died at the age of three; and Marie, who was born on 24 February 1799 and died as an infant. The following child, Augusta Marie, who was 
Table 16.1 Siblings of Margaret Ann Harvey with dates of birth and death and ages at death (based on parish registers kept in Priaulx Library)

\begin{tabular}{l|l|l|l}
\hline Name & Date of birth & Date of death & Age at death \\
\hline Margaret Ann & 18 May 1792 & 4 April 1903 & 110 \\
\hline John & 30 August 1793 & 6 September 1865 & 72 \\
\hline Elisabeth & 19 February 1796 & 28 August 1884 & 88 \\
\hline Augusta & 6 November 1797 & 11 September 1801 & 3 \\
\hline Marie & 24 February 1799 & 6 November 1799 & $<1$ \\
\hline Augusta Maria & 14 November 1801 & 16 April 1887 & 85 \\
\hline Thomas & 11 May 1803 & 10 April 1873 & 69 \\
\hline Louisa & 19 August 1806 & 4 December 1821 & 15 \\
\hline
\end{tabular}

born on 14 November 1801, was named after both girls. She died at the age of 85 . Another sister, Elisabeth, who was born on 19 February 1796, reached age 88 (Table 16.1).

During her childhood, Margaret Ann Harvey lived on Pollet Street, and went to the primary school in St Peter Port, which she left at the age of 14. In 1807, she moved with her family to Bristol, where she continued her secondary school education in a renowned school directed by Miss Cottle. There she met well-known poets from this period, such as Hazlettem, Lamb, and Macaulay, who came to Bristol to visit Miss Cottle's parents, both of whom were poets.

In 1815, just after the battle of Waterloo, she went to Brussels for further education, and especially to learn languages. She visited the battlefield of Waterloo and collected either a metal epaulette or a felt buckle; the written accounts of the visit differ on that point. Back in Bristol, she met General Dumouriez, who took part in the French Revolution, and was famous for his participation in the battles of Jemappes and Valmy. He later deserted the army and fled to the UK. In London, she also met Field Marshal Blücher, the head of the Prussian army at Waterloo. We have found no written account of the reasons for these meetings, but her oldest brother was a colonel, and some of her ancestors were officers. It also appears that she was very interested in history.

Margaret Ann married John Neve on 18 January 1823, when she was 30 years old (Fig. 16.3). Her husband had been baptised on 5 January 1779 at High Halden, Ashford Borough, Kent, England. His first wife was Ann Tanner, who died on 16 March 1816, also at High Halden.

The Priaulx Library collection in St Peter Port includes many travel journals, such as Mrs. Neve's honeymoon diaries. These diaries describe the places she visited, including the battlefield of Waterloo, which she visited for the second time 8 years after the battle.

She lived with her husband for 25 years in Tenderden in Kent. They had no children, but John had two daughters from his first marriage. John Neve died on 30 June 1849 at the age of 70, and was buried at St Mary, the Virgin Churchyard, High Halden, Ashford Borough, Kent, England. After his death, she moved back to Guernsey to live in Rouge Huis, St Peter Port. According to the 1851 census, she 


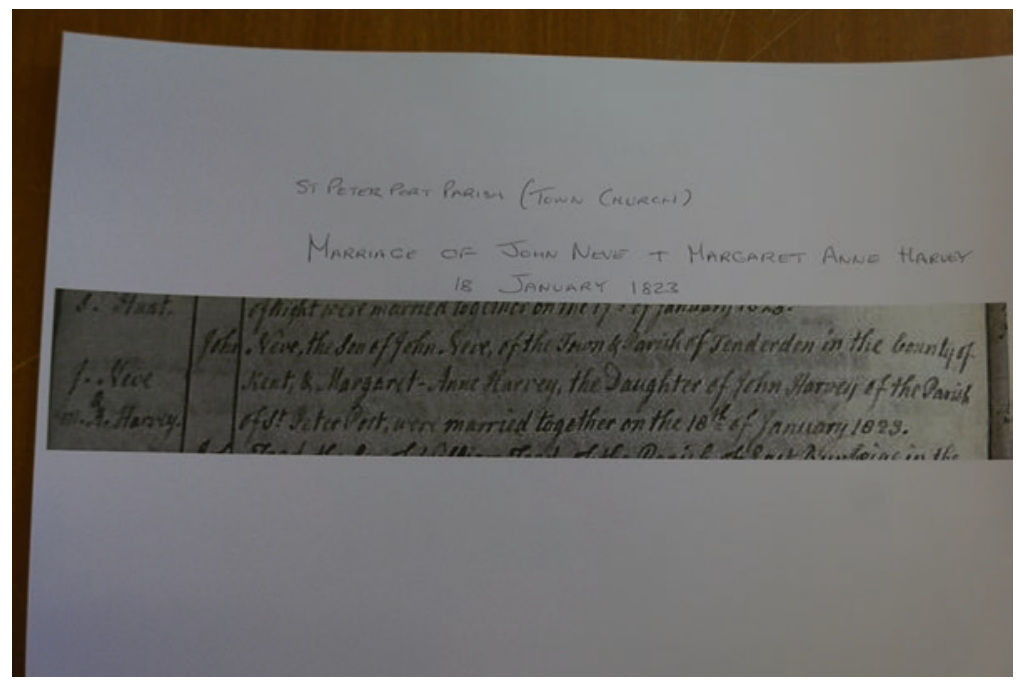

Fig. 16.3 The marriage record of John NEVE of the parish of Tenderden in the county of Kent and Margaret Ann HARVEY of the parish of St Peter Port on 18 January 1823 in Town Church (Priaulx Library)

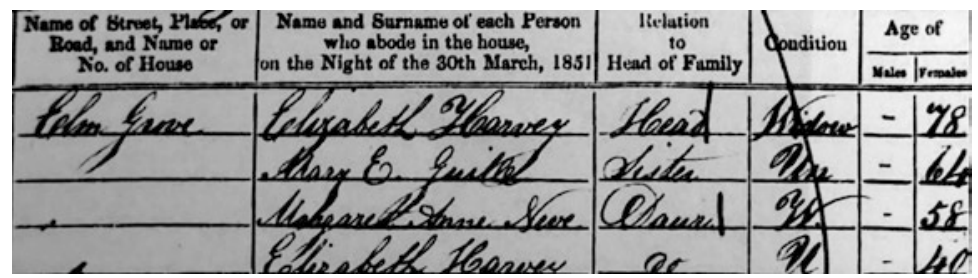

Fig. 16.4 Margaret Ann NEVEN born HARVEY, enumerated in the 1851 census with her mother Elizabeth HARVEY, aunt Mary Elizabeth GUILLE, and sister Elizabeth HARVEY

was living there on 31 March 1851 with her mother, Elisabeth Harvey, born Guille (1771-1870); her aunt, Marie Elisabeth Guille (1784-1871); and her sister, Elisabeth Harvey (1796-1884) (Fig. 16.4). Margaret's age was correctly reported in the census, but there were slight inaccuracies in the reported ages of her mother and of her aunt. There was a larger error in the reported age of her sister, who was listed as 40 years old, even though she was effectively age 55 . The same degree of underestimation also occurred in the 1861 census for both her aunt and her sister, whereas the ages of Margaret and her mother were accurately reported.

As we can see from the first photo taken around 1860, the family living in Rouge Huis was quite wealthy (Fig. 16.5). We understand from letters written by Margaret Ann to her mother when travelling abroad that their income came from investments in bonds and shares in various railways, mines, and other companies. In their 


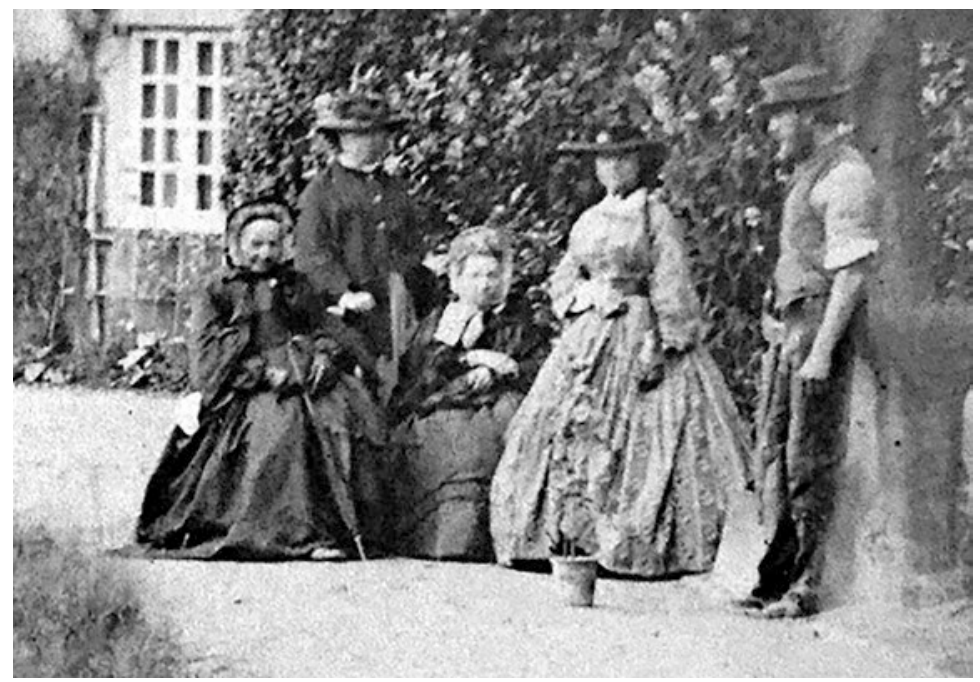

Fig. 16.5 A unique photo of the family of Margaret Ann living in Rouge Huis about 1860. From left to right: Mrs. Elisabeth Harvey (born Guille in 1771, the mother of Margaret Ann, died on 1 May 1870 at the age of 98), Miss Harvey Elisabeth (born in 1796, sister of Margaret Ann, died on 28 August 1884 at the age of 88), Miss Guille Mary Elisabeth (born in 1784, the sister of Margaret Ann's mother, died on 17 December 1871 at the age of 87), and Mrs. Margaret Ann Neve (born Harvey in 1792)

transactions of these bonds and shares, they were advised and supervised by her brother, John. While John was living with his wife and seven children in nearby St Peter Port, because he was a colonel, he spent most of his time in London. In each of Margaret Ann's letters to John during this period, her concerns and questions about these bonds and shares make up almost half of the content, with the remainder being about the education of John's seven children, which Margaret Ann and her sister were involved in. In these letters, she reports on the progress of each child in history, languages, and other disciplines.

In addition to being interested and engaged in the education of her brother's children, Margaret Ann read a great deal, especially historical books and literature. Among her favourite authors were Milton and Dante. She could read Dante in the original Italian language. She spoke French and Italian fluently. She could also read books in German and Spanish, and the New Testament in Greek.

In her daily life, needlework and gardening were important activities. She walked to the local church every Thursday and Sunday even after reaching the age of 100. Besides these daily activities, she very much liked to travel in European countries. As a young woman, she had lived in Belgium and Spain for several months. She often took the ferry to France, where she visited Paris and other places in France, and then frequently travelled from there to Italy. She also travelled farther afield, to Poland, Russia, and the Nordic countries. Her last trip abroad was to Poland in 1882, when she was 90 years old. She often travelled with her sister Elisabeth, and wrote letters to her family while she and her sister were travelling in Europe. She 
Fig. 16.6 Margaret Ann Neve, born Harvey, photographed 2 months after her 110th birthday (Island Archives)

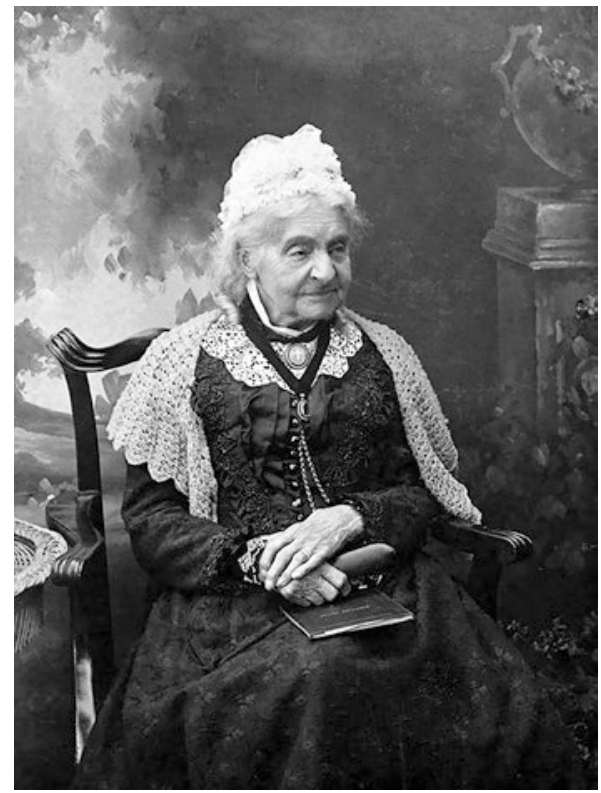

wrote numerous letters to her mother and to her brother, John, in particular. She also maintained a diary every year from 1817 to 1893 .

After the death of her mother (in 1870, at 98 years old) and her aunt (in 1871, at 87 years old), she lived alone with her sister for a period of time. Both were enumerated in the 1881 census.

After the death of her younger sister on 28 August 1884, she continued to live in Rouge Huis with other relatives. The 1901 census showed that Margaret Ann, aged 108, was living with two single nieces, the daughters of her brother John, aged 58 and 57.

Numerous articles appeared in the local press about her birthday celebrations at 100, 103, 104, 106, 107, 108, and 110 years; and we found several photos of and press releases about these celebrations in the Island Archives in St Peter Port and in Priaulx Library (Fig. 16.6). At her 100th birthday, she received congratulations from Queen Victoria.

Prior to her death, Margaret Ann had never been seriously ill, although she had the flu at the age of 105, and bronchitis at the age of 108. She could still walk in the garden at the age of 108, and she could still read large type without glasses. She was slightly deaf and slept a lot at this age. She died on 4 April 1903 at the exceptional age of 110 years and 322 days. Her death record, which is kept by the register in the Greffe of the Royal Court, confirms her parent's name and her age, and notes that she died of "décadence naturelle". She was buried in the Brothers' cemetery close to Rouge Huis. On the occasion of her burial, the flags in Guernsey were flown at half-mast. 


\subsection{Discussion}

It is our view that Margaret Ann Harvey Neve's exceptional age has been thoroughly validated by the documentation mentioned above. Thus, to our knowledge, Mrs. Neve is the first documented female supercentenarian. Considering the data collected on her parents and siblings, there is no possibility of an erroneous linkage, as her name appears only once in the birth records, her family's birth intervals were narrow, and the dates of death of all of her siblings have been checked. As she married but had no children, we found no mention of her name in the civil registration records between her marriage and her death in 1903. This lack of records might have made it difficult to prove that the person who died at age 110 in 1903 was the same person who married in 1823 at age 30 . Fortunately, she was enumerated in six successive censuses from 1851 to 1901 , and a comparison of the ages reported in these censuses and her exact ages shows only minor deviations (Table 16.2). Moreover, numerous letters and her voluminous diaries help us to follow her life during that long period. Upon reaching age 100, she became famous in Guernsey. Thus, there are many photos of her and press articles about her life. We therefore have no doubt about the validity of this exceptional case.

Table 16.2 Comparison of the age of Margaret Ann and other family members, as enumerated in successive censuses from 1851 to 1901

\begin{tabular}{|c|c|c|c|c|c|c|c|c|}
\hline \multirow{2}{*}{$\begin{array}{l}\text { Date of } \\
\text { birth }\end{array}$} & \multicolumn{2}{|c|}{$\begin{array}{l}\text { Margaret Ann Neve } \\
\text { Harvey }\end{array}$} & \multicolumn{2}{|c|}{$\begin{array}{l}\text { Elizabeth Harvey } \\
\text { Guille (mother) }\end{array}$} & \multicolumn{2}{|c|}{$\begin{array}{l}\text { Mary Elizabeth } \\
\text { Guille (aunt) }\end{array}$} & \multicolumn{2}{|c|}{$\begin{array}{l}\text { Elizabeth Harvey } \\
\text { (sister) }\end{array}$} \\
\hline & 18.5 .1792 & & 10.11 .1771 & & 25.6 .1784 & & 19.2.1796 & \\
\hline \multirow[t]{2}{*}{$\begin{array}{l}\text { Date of } \\
\text { death }\end{array}$} & \multicolumn{2}{|c|}{4.4 .1903 at 110} & \multicolumn{2}{|c|}{1.5 .1870 at 98} & \multicolumn{2}{|c|}{ 17.12.1871 at 87} & \multicolumn{2}{|c|}{28.8 .1884 at 88} \\
\hline & $\begin{array}{l}\text { Age } \\
\text { reported at } \\
\text { census }\end{array}$ & $\begin{array}{l}\text { Exact } \\
\text { age }\end{array}$ & $\begin{array}{l}\text { Age } \\
\text { reported at } \\
\text { census }\end{array}$ & $\begin{array}{l}\text { Exact } \\
\text { age }\end{array}$ & $\begin{array}{l}\text { Age } \\
\text { reported at } \\
\text { census }\end{array}$ & $\begin{array}{l}\text { Exact } \\
\text { age }\end{array}$ & $\begin{array}{l}\text { Age } \\
\text { reported at } \\
\text { census }\end{array}$ & $\begin{array}{l}\text { Exact } \\
\text { age }\end{array}$ \\
\hline $\begin{array}{l}30 \\
\text { March } \\
1851\end{array}$ & 58 & 58 & 78 & 79 & 64 & 66 & 40 & 55 \\
\hline $\begin{array}{l}7 \text { April } \\
1861\end{array}$ & 65 & 68 & 89 & 89 & 70 & 76 & 56 & 65 \\
\hline $\begin{array}{l}2 \text { April } \\
1871\end{array}$ & 78 & 78 & & & 86 & 86 & 73 & 75 \\
\hline $\begin{array}{l}3 \text { April } \\
1881\end{array}$ & 88 & 88 & & & & & 85 & 85 \\
\hline $\begin{array}{l}5 \text { April } \\
1891\end{array}$ & 98 & 98 & & & & & & \\
\hline $\begin{array}{l}31 \\
\text { March } \\
1901\end{array}$ & 108 & 108 & & & & & & \\
\hline
\end{tabular}


Acknowledgements We greatly thank the following for helping us to find and to take copies of the documents in the different archives:

- Miss Sue LAKER, Deputy Chief Librarian and Dinah BOTT, Communications Assistant, both at the Priaulx Library

- Nathan Coyde, Archives Manager, Island Archives, States of Guernsey

- Steve Payne, Head Clerk to the Strongroom, The Greffe, States of Guernsey

\section{References $^{1}$}

Mrs. Neve's 100th birthday. Many beautiful bouquets. The Star, 19th May, 1892. (1)

Miastress Neve. Another bouquet. 25th May, Daily Telegraph, 1892. (2)

West, W. One of the Queens oldest subjects. The Star, 25th July, 1895. (3)

"Unexampled longevity". The Pall Mall Gazette, 18th June 1899. (4)

A Guernsey Centenarian. Memories of Waterloo. The Star, 17th November, 1900. (5)

"Her Hundred-and-eighth Birthday", The Pall Mall Gazette, 18th May 1900. (6)

"The Oldest Woman in the World". Richmond Examiner, 19th February 1901. (7)

"The late Mrs Neve", NY Times, 19th April 1903. (8)

"Aged 110 years". The Straits Times, 7th May 1903. (9)

Guernsey Press announcements of her 100, 103, 104, 106, 107, 108 and 110. (10)

Pannett, Peter. Oldest woman watched 1900 solar event. Guernsey Press, 7th August, 1999. (11)

Priaulx TF. The Old Lady of Rouge Huis. Quarterly Review of the Guernsey Society 1972; XXVIII (No. 1): 11-14. (12)

Harvey/Neve Letters 1845-1902, from the collection at The Priaulx Library Guernsey. (13)

Harvey Diaries headed Neve, 1817-1893 (some years missing) at The Island Archives, States of Guernsey. (14)

Open Access This chapter is licensed under the terms of the Creative Commons Attribution 4.0 International License (http://creativecommons.org/licenses/by/4.0/), which permits use, sharing, adaptation, distribution and reproduction in any medium or format, as long as you give appropriate credit to the original author(s) and the source, provide a link to the Creative Commons license and indicate if changes were made.

The images or other third party material in this chapter are included in the chapter's Creative Commons license, unless indicated otherwise in a credit line to the material. If material is not included in the chapter's Creative Commons license and your intended use is not permitted by statutory regulation or exceeds the permitted use, you will need to obtain permission directly from the copyright holder.

\footnotetext{
${ }^{1}$ This chapter is based on the documents we found in the archives in the Priaulx Library, the Island Archives of the States of Guernsey, and in the Greffe of the Royal Court, all in St Peter Port; as well as on our review of numerous articles in the press (1-11), an article in The Quarterly Review of the Guernsey Society (12), a transcription of the Harvey/Neve letters 1845-1902 stored at The Priaulx Library Guernsey (13) and the Harvey Diaries headed Neve, 1817-1893 (some years missing) at The Island Archives, States of Guernsey (14).
} 